\title{
Thermostable Alkaline Protease Activity from Aspergillus flavus DUCC- K225 and Its Compatibility to Local Detergents
}

\author{
ALMALINA NABILA SULISTYO RINI, ISWORO RUKMI*, AND SRI PUJIYANTO
}

\author{
Department of Biology, Faculty of Science and Mathematics, Universitas Diponegoro \\ Jl. Prof Soedharto, SH, Tembalang, Semarang 50275, Indonesia.
}

\begin{abstract}
Protease important enzyme in many industries, including detergent. Aspergillus flavus DUCC-K225 is a thermotolerant indigenous molds isolated from Madura island which is potential in producing thermostable alkaline protease enzymes. The enzyme produced by submerged culture on modified Czapeks Dox liquid medium containing glucose as carbon source and $1 \%$ of casein. The aims of this study were to determine the activity and stability of thermostable alkaline protease produced by $A$. flavus DUCC-K225 at various temperatures, also the compatibility to 5 local detergents. Research were conducted using Completely Randomized Design in triplicate, with temperature variation for protease activity as treatment. The results showed that the highest activity of thermostable alkaline proteases was $214.503 \mathrm{U} / \mathrm{mL}$, with retained activities up to $78 \%$ in 60 minutes at $55^{\circ} \mathrm{C}$. This enzyme compatible with 5 local detergents tested, with the retained activity varied $59.48 \%-99.48 \%$ at $29^{\circ} \mathrm{C}$ and $62.83 \%-98.05 \%$ at $55^{\circ} \mathrm{C}$. The compatibility to all detergent tested were confirmed by the increament of blood solubility.
\end{abstract}

Key words: alkaline protease, A. flavus DUCC-K225, compatibility, detergent, thermostable

Protease merupakan enzim yang penting untuk industri, termasuk industri deterjen. Aspergillus flavus DUCC-K225 merupakan kapang termotoleran indigenous dari Pulau Madura, yang berpotensi menghasilkan enzim protease alkalis termostabil. Produksi enzim dilakukan dalam kultur terendam pada medium Czapexs Dox broth yang mengandung glukosa sebagai sumber karbon, dan kasein 1\%. Tujuan dari penelitian ini untuk mengetahui aktivitas dan stabilitas ensim protease alkalis yang dihasilkan oleh A. flavus DUCC-K225 pada berbagai suhu, serta kompatibilitasnya terhadap 5 jenis deterjen lokal. Hasil yang diperoleh menunjukkan bahwa ensim tetap stabil pada suhu $55^{\circ} \mathrm{C}$ yang menunjukkan bahwa ensim ini termostabil, Aktivitas tertinggi ensim ini adalah $214.503 \mathrm{U} / \mathrm{mL}$, dengan aktivitas yang dipertahankan sebesar $59.48 \%-99,48 \%$ pada suhu $29^{\circ} \mathrm{C}$ dan $62.83 \%$ $98,05 \%$ pada suhu $55^{\circ} \mathrm{C}$. Ensim ini kompatibel terhadap semua deterjen yang diujikan, karena dapat meningkatkan kelarutan noda darah pada kain.

Kata kunci: A.flavus DUCC-K225, deterjen, kompatibilitas, protease alkalis, termostabil

Protease (EC 3.4) is an enzyme that able to hydrolyze the peptide bonds between amino acids in proteins (Nallusami, Remya \& Al-Bahri 2009). The availability of proteases is important for several industries, especially the proteases which are stable at high temperature and $\mathrm{pH}$ According to Gupta et al. (2002) and Chimbekujwoa et al. (2020) some industries need thermostable alkaline proteases which is active at $\mathrm{pH} 8-12$ and temperatures of $50^{\circ} \mathrm{C}-70^{\circ} \mathrm{C}$. The presence of alkaline proteases is one of the 3 major groups of enzymes needed in industrial processes, which have a contribution of $60 \%$ in the sale of enzymes worldwide (Sahib 2009; Lanka, Anjali, \& Pydipalli 2017, Chimbekujwoa et al. 2020). Protease enzymes can be obtained from various sources such as plants, animals and microorganisms that are widespread in

*Corresponding author: Phone: +62-811288428; Fax: +62-; E-mail:mgiswororukmi@lecturer.undip.ac.id nature, including in extreme environment (Coral et al. 2003). Some microorganisms have the potential to produce thermostable alkaline proteases, among others are fungi that can produce many kinds of extracellular enzymes. The enzyme production from fungi has several advantages, because the enzymes are more easily obtained in submerged fermentation, easily separated from the medium, and can be grown on a cheap medium (Souza et al. 2015; Soares et al. 2010). According to Souza et al. (2015) the mold of the genus Aspergillus widely known as a largest producer of alkaline proteases, such as Aspergillus flavus which has been known as a species that generally has a high ability in producing extracellular protease. The production of microbial enzymes were influenced by the medium composition, while the enzyme activity affected by the incubation temperature (Packianathan $e t$ al. 2008). The aims of this study were to examined the production of thermostable alkaline protease from 
indigenous thermotolerant fungi Aspergillus flavus DUCC-K225 isolated from lime soil in Madura Island, East Java using glucose as carbon source and examined the effect of temperature on the enzyme activity, as well as the enzyme compatibility to local detergents.

\section{MATERIALS AND METHODS}

\section{Culture Maintenance and Inoculum} Preparation. The mold A. flavus DUCC-K225 was maintained on PDAAgar slant, and sub cultured before used in the study. The spore inoculum was prepared by adding sterile distilled water containing $1 \%$ of Tween 80 into 5 days old mold culture on PDA (Coral et al. 2003).

Enzyme Production. The fungal alkaline protease from A. flavus DUCC-K225 produced according to Coral et al. (2003) and Packianathan et al. (2008) by submerged fermentation in the modified Czapeks Dox medium composed of $30 \mathrm{~g} / \mathrm{L}$ glucose; $0.5 \mathrm{~g} / \mathrm{L} \mathrm{KCl}$; $0.01 \mathrm{~g} / \mathrm{L} \mathrm{FeSO}_{4} ; 0.5 \mathrm{~g} / \mathrm{L} \mathrm{MgSO}_{4} ; 1 \mathrm{~g} / \mathrm{L} \mathrm{K}_{2} \mathrm{HPO}_{4} ; 2 \mathrm{~g} / \mathrm{L}$ $\mathrm{NaNO}_{3}$, and $1 \%$ casein. The media $\mathrm{pH}$ was arranged at 9. One percent fungal spores suspension of $A$. flavus DUCC-K225 $\left(10^{8} / \mathrm{ml}\right)$ inoculated into the medium, the flasks were then incubated on rotary shaker with 120 rpm for 7 days at room temperature. The fungal cultures filtered using Whatman paper. No. 1, the supernatant obtained centrifuged at $4000 \mathrm{rpm}$ for 20 minutes and use as crude enzymes.

Protease Assay. The protease activity was measured by modified method of Keay et al. (1970 in Coral et al. 2003; Rani \& Prasad 2013; Chimbekujwoa 2020) using casein as substrate. One $\mathrm{ml}$ of culture supernatant was mixed thoroughly with $1 \mathrm{ml}$ of $2 \%$ of casein solution, incubated at $37^{\circ} \mathrm{C}$ for $10 \mathrm{~min}$ and the reaction was stopped by adding $2 \mathrm{ml}$ of $0.4 \mathrm{M}$ trichloroacetic acid and incubated for $20 \mathrm{~min}$ at $37^{\circ} \mathrm{C}$. The solution filtered using Whatman No. 1 paper. One $\mathrm{ml}$ of filtrate then mixed thoroughly with $5 \mathrm{ml}$ of $0.4 \mathrm{M}$ $\mathrm{Na}_{2} \mathrm{CO}_{3}$ and $1 \mathrm{ml}$ of $0.5 \mathrm{~N}$ Folin phenol reagent, incubated at $37^{\circ} \mathrm{C}$ for $20 \mathrm{~min}$. The absorbance of the final solution was measured at $660 \mathrm{~nm}$. One unit of protease activity was defined as the amount of enzyme required to liberate $1 \mu \mathrm{mol}$ of tyrosine in $20 \mathrm{~min}$ at $37^{\circ} \mathrm{C}$.

Thermostability Assay. The enzyme thermostability examined according to Kamoun et al. (2008) by measuring the enzyme activity for 1 hour at various temperatures with interval of 15 minutes at $\mathrm{pH}$ 9.8. Thermal stability of enzyme was determined by incubating $2 \mathrm{~mL}$ of culture supernatant mixed with $2 \%$ casein solution for 60 minutes at $29^{\circ} \mathrm{C}, 40^{\circ} \mathrm{C}, 45^{\circ} \mathrm{C}$, $50^{\circ} \mathrm{C}, 55^{\circ} \mathrm{C}$, and $60^{\circ} \mathrm{C}$. The unheated enzyme was used as control.

Compatibility to Commercial Detergents. The alkaline protease of A. flavus DUCC-K225 was tested for its compatibility to 5 commercial detergents i.e. B, D, S, R, and J, according to Choudhary (2012). A detergent solution of $0.7 \mathrm{~g} / 100 \mathrm{~mL}$ were heated at $100^{\circ} \mathrm{C}$ for 1 hour, to destroy indigenous protease that might be present. The detergent solution mixed with the culture supernatant in a ratio of $1: 1(\mathrm{v} / \mathrm{v})$ incubated at $40^{\circ} \mathrm{C}$ for $20 \mathrm{~min}$. The residual protease activity examined using standard assay procedure as mentioned previously. A mixture of culture supernatant and tap water (1:1) used as control $100 \%$. The relative enzyme activity was expressed as percentage activity considering the activity of control. The enzyme activities were examined in 3 treatments, i.e. $0.3 \mathrm{~mL}$ of culture supernatant mixed with $5.7 \mathrm{~mL}$ of detergent solution $(0.7 \mathrm{~g} / 100 \mathrm{~mL}) ; 0.3 \mathrm{~mL}$ of detergent solution $(0.7 \mathrm{~g} / 100 \mathrm{~mL})$ mixed with $5.7 \mathrm{~mL}$ of distilled water; and $0.3 \mathrm{~mL}$ of culture supernatant mixed with $5.7 \mathrm{~mL}$ of distilled water. The enzyme assays conducted at room temperature $\left(29^{\circ} \mathrm{C}\right)$ and the optimum temperature of protease activity which previously obtained $\left(55^{\circ} \mathrm{C}\right)$.

Cleansing Power as Additive in Local Detergents. The cleansing power of the enzyme carried out based on Niyonzima \& More (2015) by soaking a piece of $4 \times 4 \mathrm{~cm}$ square white cloth which have been stained with blood in 4 solutions, containing (1) $50 \mathrm{~mL}$ of distilled water, $1 \mathrm{~mL}$ of culture supernatant and $1 \mathrm{~mL}$ of detergent solution $(0.7 \mathrm{~g} / 100 \mathrm{~mL})$ which has been heated before at $100^{\circ} \mathrm{C}$ for 1 hour; (2) $51 \mathrm{~mL}$ of distilled water and $1 \mathrm{~mL}$ culture supernatant; (3) $51 \mathrm{~mL}$ of distilled water and $1 \mathrm{~mL}$ of detergent solution $(0.7 \mathrm{~g}$ $/ 100 \mathrm{~mL}$ ) heated at $100^{\circ} \mathrm{C}$; and (4) $52 \mathrm{~mL}$ of distilled water as control. The bloodstained clothes were soaked in the solution at room temperature $\left(29^{\circ} \mathrm{C}\right)$ and $55^{\circ} \mathrm{C}$ for 10 minutes. The clothes were then dried and visually observed for the stain removal. The blood solubility in the soaking solution were also observed by measuring the absorbance at $\lambda_{200}$.

\section{RESULTS}

Effect of Temperature on Protease Activity. The protease activity examination at various temperatures carried out to obtain the optimum temperature of $A$. flavus DUCC-K225 protease. Figure 1, showed that the activity of alkaline protease increased along with the temperature increment. The highest protease activity reached at $55^{\circ} \mathrm{C}$ with the value of $214,50 \mathrm{U} / \mathrm{mL}$, 
Table 2 The compatibility of $A$. flavus DUCC-K225 alkaline protease to various detergents

\begin{tabular}{ccccc}
\hline \multirow{2}{*}{ Detergents* } & \multicolumn{2}{c}{ Protease activity $(\mathbf{U} / \mathbf{m L})$} & \multicolumn{2}{c}{ Retained activity (\%) } \\
\cline { 2 - 5 } & $\mathbf{2 9}{ }^{\circ} \mathbf{C}$ & $\mathbf{5 5}^{\circ} \mathbf{C}$ & $\mathbf{2 9}^{\circ} \mathbf{C}$ & $\mathbf{5 5}^{\circ} \mathbf{C}$ \\
\hline \multirow{2}{*}{ Enzyme } & $66.76 \pm 1.46$ & $111.77 \pm 2.70$ & 100.00 & 100.00 \\
B & $61.55 \pm 2.83$ & $102.23 \pm 1.33$ & 92.19 & 91.47 \\
D & $57.01 \pm 1.29$ & $99.42 \pm 2.19$ & 85.39 & 88.96 \\
J & $48.11 \pm 1.78$ & $85.43 \pm 2.83$ & 72.07 & 76.44 \\
R & $39.71 \pm 2.70$ & $70.22 \pm 3.10$ & 59.48 & 62.83 \\
S & $66.41 \pm 2.66$ & $109.58 \pm 1.66$ & 99.48 & 98.05 \\
\hline
\end{tabular}

Table 3 The compatibility of $A$. flavus DUCC-K225 alkaline protease to various detergents

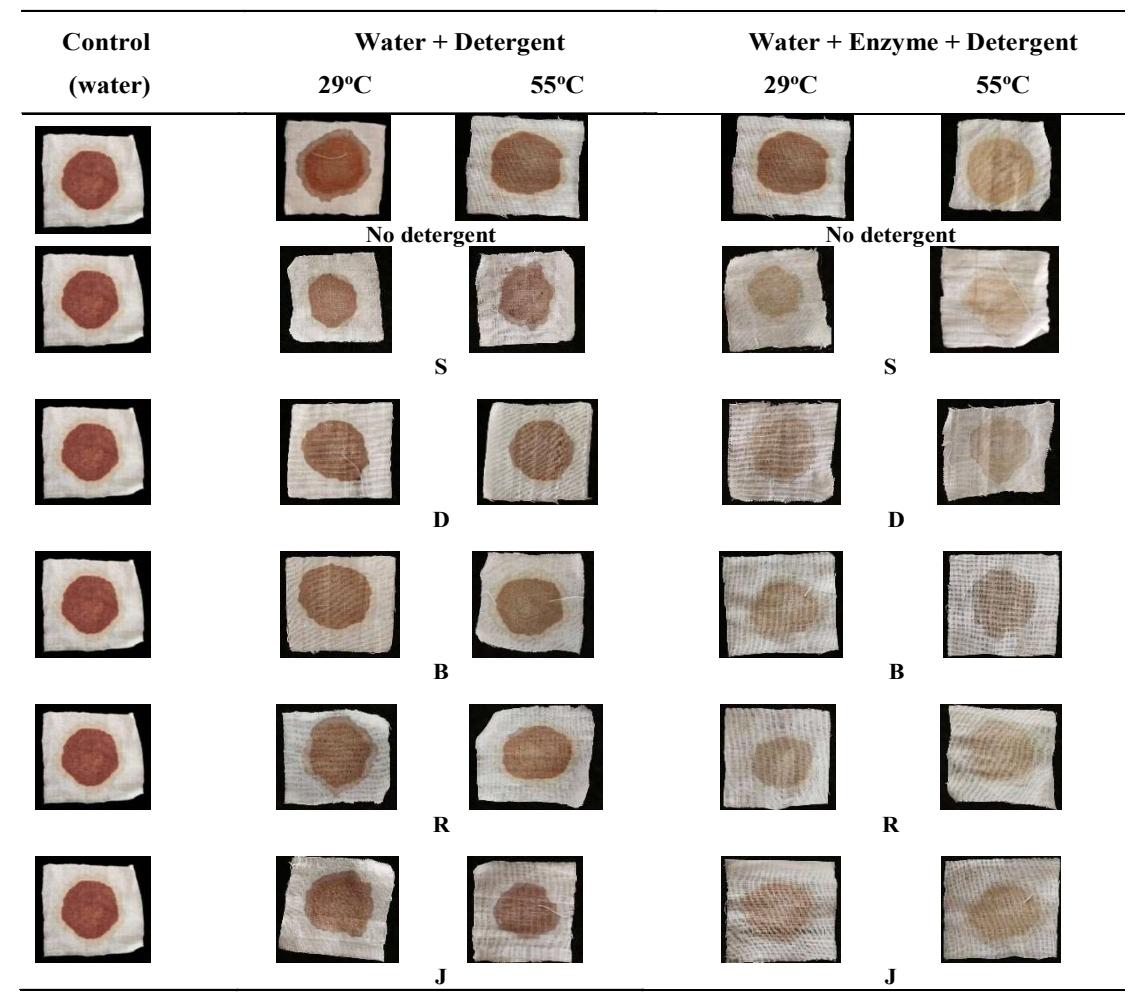

although it is statistically at par with $50^{\circ} \mathrm{C}$ and $60^{\circ} \mathrm{C}$.

Thermostability of Alkaline Protease. The enzyme thermostability have been examined at the optimum temperature of $55^{\circ} \mathrm{C}$, which obtained from previous examination of temperature effect on protease activity. The result showed that the enzyme was still active for 60 minutes with retained activity value of $77.8-78.8 \%$ (Fig 2).

Compatibility with Detergents. The detergent compatibility test was carried out at room temperature $\left(29^{\circ} \mathrm{C}\right)$ and $55^{\circ} \mathrm{C}$ to determine the ability of A. flavus DUCC-K225 thermostable alkaline protease as additive for commercial detergents. The enzyme compatibility to detergents determined by the retained activity value of enzyme in the detergent solutions. Table 2 showed that the retained activity of the enzyme in the detergent solution were varied. in three commercial detergents, which is in $\mathrm{D}, \mathrm{J}$ and $\mathrm{R}$ were slightly higher at $55^{\circ} \mathrm{C}$ than at $29^{\circ} \mathrm{C}$, while for B and $\mathrm{S}$ detergent were slightly higher at $29^{\circ} \mathrm{C}$ than at $55^{\circ} \mathrm{C}$ (Table 2), but not different significantly.

Cleansing Potential as Detergent Additive. The effect of alkaline protease produce by A.flavus DUCCK225 on detergent's cleansing power was carried out by soaking the blood stained fabrics in the detergent solution mixed with enzyme at two different temperature. The visually examination found that the enzyme increased the detergent's removing power of the blood stain from the fabrics (Table 3). The measurement of soaking solution's absorbance at $\lambda_{200}$ were carried out to ensure that the blood dissolved to the water. The obtained of absorbance values were higher at $55^{\circ} \mathrm{C}$ than at $29^{\circ} \mathrm{C}$ indicated that more dissolved blood occurred at higher temperature (Fig 3). The highest absorbance showed on the enzyme and $\mathrm{S}$ detergent mixed solution, this result in line with the 


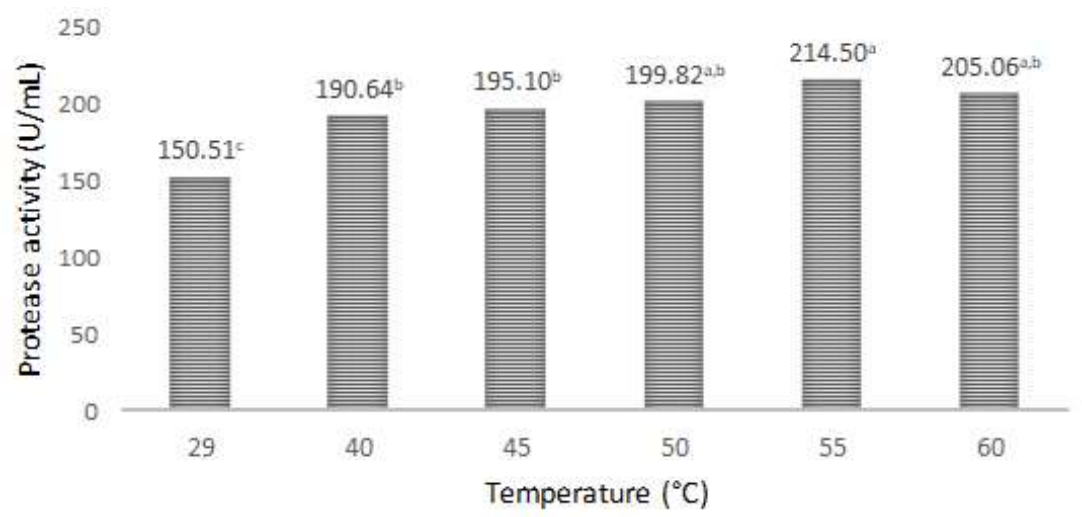

Fig 1 The effect of temperature on the alkaline protease activity of $A$. flavus DUCC-K225.

Remarks: the same superscripts show no significantly difference $(\mathrm{p}<0.05)$.

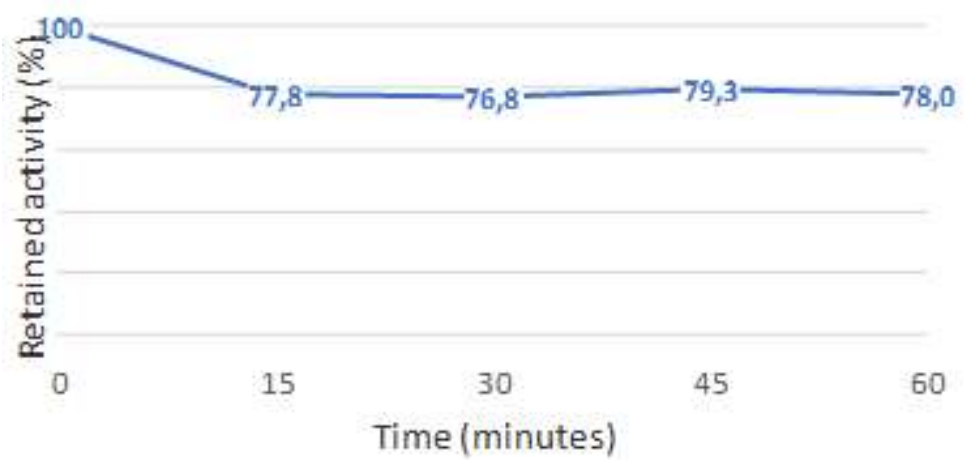

Fig 2 The stability of alkaline protease enzyme produced by $A$. flavus DUCC-K 225 at $55^{\circ} \mathrm{C}$.

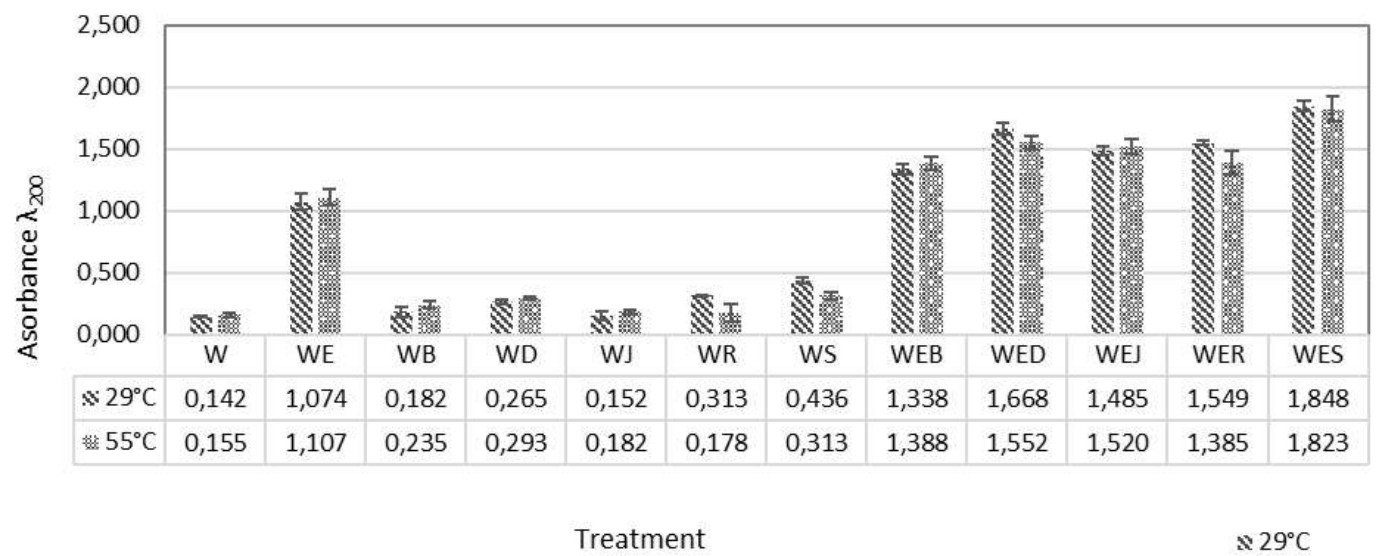

Fig 3 The blood stain solubility in the soaking water.

W- water; E- enzyme; B,D,J,R,S - detergents.

value of detergent's compatibility (Table 2).

\section{DISCUSSION}

Aspergillus flavus DUCC K225 is an indigenous mold isolated from lime soil of Madura Island. The temperature of the sampling site was $38^{\circ} \mathrm{C}$ with the $\mathrm{pH}$ of 8.3. This fungus can grow up to $45^{\circ} \mathrm{C}$ at the $\mathrm{pH} 8$ on PDA medium and showed proteolytic activity with the index of 1.38. Based on the data obtained, study in the production of alkaline thermotolerant protease from this isolate were conducted, to examine on the thermotolerant characteristic and the compatibility to comercial detergent. The result of protease activity from A. flavus DUCC K225 examination showed that the enzyme is a thermostable one. The enzyme activity at $55^{\circ} \mathrm{C}-60^{\circ} \mathrm{C}$ higher than at lower temperatures (Fig.1.), this indicates that the enzyme structure remains stable up to $60^{\circ} \mathrm{C}$. According to Yeoman et al., (2010) the thermostable enzymes can maintain their 
structural integrity at above $55^{\circ} \mathrm{C}$. Coral et al. (2003) reported the thermostable alkaline protease produced by an Aspergillus niger strain which is stable at $40^{\circ} \mathrm{C}$, while alkaline protease from A. flavus AS2 studied by Rani \& Prasad (2013) found stable at $55^{\circ} \mathrm{C}$. Based on previous data obtained in this study, the temperature of $55^{\circ} \mathrm{C}$ was stated as optimum temperature of this protease. The observation at $55^{\circ} \mathrm{C}$ showed that this enzyme still active for 60 minutes with $78 \%$ retained activity (Fig. 2.). This result supported the previous indication that the alkaline protease produced by $A$. flavus DUCC-K225 was thermostable. The similar result also found in previous study on the alkaline proteinases which produced by Aspergillus fumigatus Fresenius TKU003 and Aspergillus terreus which is thermostable at $50^{\circ} \mathrm{C}$ and $60^{\circ} \mathrm{C}$ (Nirmal et al. 2011). The enzyme retained activity value of the alkaline protease produced by A. flavus DUCC-K225 in five commercial detergents (Fig 3), indicated that this enzyme compatible with all detergents tested. Choudhary (2012), Niyonzima \& More (2015) and Devi et al (2008) have been reported that the alkaline protease from several Aspergillus species were compatible to detergents. The stability of enzyme was strong related to the retained activity in detergent solutions. The differences in enzyme stability of $A$. flavus DUCC K225 in the five detergent solution used, may corelated with detergent ingredient. Surfactant is one of the main ingredient in commercial detergents, which have the ability to interact with proteases in increasing or inhibiting protease activity (Zhang \& Zhang 2015). The detergent S, B, and D contained Sodium Alkyl Benzene Sulfonate as surfactant with the concentrations of $22 \%, 20 \%$ and $15 \%$ respectively, while $\mathrm{J}$ and $\mathrm{R}$ detergents contained $16 \%$ and $19 \%$ surfactant respectively, but the types of surfactant were not clearly defined. According to Samanta \& Mitra (2004) there are 4 groups of surfactants, i.e. anionic surfactants, non-ionic surfactants, cationic surfactants, and amphoteric surfactants. An anionic surfactants such as Sodium Alkyl Benzene Sulfonate also known as Linear Alkyl Benzene Sulfonate (LAS) have the greatest effect on protease activity, compared to other anionic surfactants such as Sodium Duodesyl Sulfate (SDS) and Sodium Lauryl Sulfate (SLS) (Zhang \& Zhang 2015). The protease activity will be increased or persists constantly when the concentration of anionic surfactants increases (Barberis et al 2013). The low concentration of LAS in water solution $(<20 \%)$ caused low protease activity, whereas in the high concentration $(>45 \%)$ caused enzyme denaturation.
The highest compatibility of the alkaline protease from A. flavus DUCC-K225 shown in S detergent which is contained $20 \%$ LAS as surfactant, with the activity retained $99.48 \%$ and $98.05 \%$ at $29^{\circ} \mathrm{C}$ and $55{ }^{\circ} \mathrm{C}$ respectively. The ability of alkaline protease of $A$. flavus DUCC-K225 in removing blood stains on cloth indicates that this enzyme has the potential to be used in detergent formulas (Tambekar \& Tambekar 2013). Shahid \& Ahmed (2016) stated that proteases capable in removing proteinic stains such as blood, often used in various detergent industries. The alkaline protease of A. flavus DUCC-K225 showed highest compatibility to $\mathrm{S}$ detergent, hence the A. flavus DUCC-K225 alkaline protease potentially developed to be applied as detergent additives.

\section{REFERENCES}

Barberis S, Quiroga E, Barcia C, Liggieri C. 2013. 'Effect of Laundry Detergent Formulation on The Performance of Alkaline Phytoproteases', Electro. J. Biotechnol., 16: 1-15, DOI:10.2225/vol16-issue3-fulltext-1.

Chimbekujwoa KI, Ja'afarua MI, Adeyemo OM. 2020. Purification, characterization and optimization conditions of protease produced by Aspergillus brasiliensis strain BCW2. Scientific African 8:1-9. https://doi.org/10.1016/j.sciaf.2020.e00398.

Choudhary V. 2012, 'Compatibility with Commercial Detergents and Stain Removal Capability of Aspergillus versicolor Protease' J. Acad. Indus. Res., 1(1): pp. 301-305. ISSN: 2278-5213.

Coral G, Arikan B, Unaldi MN, Guvenmez H 2003, 'Thermostable Alkaline Protease Produced by An Aspergillus niger Strain', Ann. Microbiol. 53:491-498.

Devi MK, Banu AR, Gnanaprabhal GR, Pradeep BV,Palaniswamy M . 2008. 'Purification, Characterization of Alkaline Protease Enzyme from Native Isolate Aspergillus niger and Its Compatibility with Commercial Detergents', Ind.. J. Sci. Technol., 1:1-6, DOI:10.17485/ijst/2008/v1i7.8.

Gupta, R, Beg, Q, Khan, S. Chauhan, B. 2002. 'An Overview on Fermentation, Downstream Processing and Properties of Microbial Alkaline Proteases', Appl. Microbiol. Biotech., 60:381-395, DOI:10.1007/s00253-002-1142-1.

Kamoun AS, Hadar A, Ali NE, Ghorbel B, Kanoun S, Nasri M. 2008.'Stability of Thermostable Alkaline Protease from Bacillus licheniformis RP-1 Commercial Solid Laundry Detergent Formulations', Microbiol. Res., 163:299-306, DOI:10.1016/j.micres.2006.06.001.

Lanka S, Anjali CH. Pydipalli M. 2017. 'Enhanced Production of Alkaline Protease by Aspergillus niger 
DEF 1 Isolated from dairy form effluent and Determination of Its Fibrinolytic Abilility', Afr. $J$. Microbiol. Res. 11:440-449, DOI:10.5897/AJMR2016-8379.

Nallusami SR, Remya A, Al-Bahry S. 2009, 'Partial Characterization of Proteases Produced by Three Fungal Isolates from The Rhizosphere of Wild Yam Dioscorea wallicnii', J. Appl. Biol. Sci., 3(3):71-75.

Nirmal NP, Shanka S, Laxman RS. 2011. 'Fungal Proteases: An Overview', Int. J. Biotech \& Biosci., 1: 1-40.

Niyonzima, FN , More, SS. 2015. 'Purification and Characterization of Detergent-Compatible Protease from Aspergillus terreus gr', Biotech., 5: 61-70, DOI:10.1007/s13205-014-0200-6.

Packianathan, C, Devanathan, V, Anbu, P, Ponnuswamy, MN, Kalaichelvan, PT, Hur, BK. 2008, 'Purification, characterization and crystallization of an extracellular alkaline protease from Aspergillus nidulans HA-10', $J$. Bas. Microbiol. 48 (5):347-352, DOI:10.1002/jobm.200800043.

Rani, MR, Prasad, NN.2013, 'Studies on Purification of Alkaline Protease from a Mutant Aspergillus flavus AS2', Res. J. Biotechnol., 8(3): 58-66.

Sahib RA. 2009. 'Study of Optimum Condition for Alkaline Protease Production from Local Isolate of Aspergillus niger', Iraqi J. Sci., 50: 476-481.

Samanta AK, Mitra S. 2004, 'Efficacy of Selective Surfactants/Detergents as Washing Agents on Soiled White and Dyed Cotton Fabrics', Ind. J. Fiber Text. Res., 29: 223-232.
Shahid SMT \& Ahmed K. 2016, 'Enzyme Proteases Used in Laundry Detergents Engineering', Sci. Int. 28: 27112717. ISSN 1013-5316.

Soares FEF, Fabio RB, Hugo LAG, Jackson VdeA, Sebastiao RF, Juliana MA, Alexandre OT, Vinicus, LRV, Jose HQ. 2010, 'Optimization of Medium Composition for Protease Production by Paecilomyces marquandi in Solid-State-Fermentation using Response Surface Methodology', Afr. J. Microbiol. Res. 4:2699-2703. ISSN 1517-8382.

ISouza PM, Bittencourt MLA, Caprara CC, Freitas M, Almeida RPC, Silveira D, Fonseca YM, Filho EXF, Junior A, Magalhaes PO. 2015, 'A Biotechnology Perspective of fungal Proteases', J. Microbiol. 46(2): 337-346, DOI:10.1590/S1517-838246220140359.

Tambekar SD, Tambekar DH. 2013, 'Compatibility and Wash Performance Analysis of Alkaline Protease from Bacillus pseudofirmus (JQ337958) with Commercial Detergents', Int. J. Pharma. Chem. Biol. Sci., 3: 738744. ISSN: 2249-9504.

Yeoman CJ, Han Y, Dodd D, Schroeder CM, Mackie RI, Cann, IKO. 2010, 'Thermostable Enzymes as Biocatalysts in the Biofuel Industry', Adv. Appl. Microbiol.70: 1-55, Elsevier Inc. ISSN 0065-2164, DOI:10.1016/S0065-2164(10)70001-0.

Zhang J, Zhang J. 2015, 'Study on The Interaction of Alkaline Protease with Main Surfactants in Detergent', Coll. Polym. Sci., 124: 1-9, DOI:10.1007/s00396-0153777-3. 